\title{
ANALISIS MANAJEMEN EVENT DI KYRIAD HOTEL BUMIMINANG PADANG
}

\author{
Tika Putri Adhitama ${ }^{1}$, Lise Asnur ${ }^{3}$ \\ ${ }^{1,2}$ Program Studi D4 Manajemen Perhotelan, Jurusan Pariwisata \\ FPP Universitas Negeri Padang \\ e-mail: lise.asnur@fpp.unp.ac.id
}

\begin{abstract}
Abstrak
Penelitian inimbertujuan untuk mengetahui Analisis Manajemen Event di Kyriad Hotel Bumiminang Padang. Penelitian ini terdiri dari 4 indikator fungsi manajemen yaitu: perencanaan, pengorganisasian, pelaksanaan dan pengawasan. Penelitian ini merupakan penelitian deksriptif dengan pendekatan data kuantitatif dan kualitatif metode mixed. Populasi pada penelitian ini sebanyak 653 orang. Teknik pengambilan sampel mengunakan Proporsional Random Sampling, dengan jumlah sampel sebanyak 87 orang. Data dikumpulkan melalui wawancara dan menyebarkan kuesioner (angket) dengan mengunakan skala Likert yang telah teruji validitas dan reliabilitasnya. Hasil penelitian menunjukkan bahwa manajemen event di Kyriad Hotel Bumiminang masih memiliki beberapa kendala dan kekurangan ditinjau dari perencanaan, pengorganisasian, pelaksanaan dan pengawasan. Berdasarkan data analisis dengan IBM SPSS versi 25, menunjukkan bahwa (1) manajemen event kategori kurang baik persentase $62 \%$. (2) indikator perencanaan kategori kurang baik persentase $51 \%$. (3) indikator pengorganisasian kategorin kurang baik persentase $72 \%$. (4) indikator pelaksanaan kategori cukup baik persentase $38 \%$. (5) indikator pengawasan kategori cukup baik persentase $44 \%$.
\end{abstract}

Kata kunci : Manajemen Event, Perencanaan, Pengorganisasian, Pelaksanaan, Pengawasan, Hotel.

\begin{abstract}
This research aims to determine the analysis of event management in Kyriad Hotel Bumiminang Padang. This research is consist of four indicators are: planning, organizing, actuating and controlling. The type of this research is descriptive research with quantitative and qualitiative data approaches with mixed method. The population in this research is 653 people. The sampling technique is using proportional random sampling with total sample is 87 people. Data is collected through interview and distributing questionnaires using likert scale that has been tested for validity and reliability. The results showed that event management in Kyriad Hotel Bumiminang Padang still had several obstacles and shortcomings in terms of planning, organizing, actuating and controlling. Based on data analysis with IBM SPSS version 25, shows that (1)event management category is not good with percentage $62 \%$. (2) planning indicator category is not good with percentage $51 \%$. (3) organizing indicator category is not good with percentage $72 \%$. (4) actuating indicator category is quite good with percentage $38 \%$. (5) controlling indicator category is quite good with percentage $44 \%$.
\end{abstract}

Keywords : Event Management, Planning, Organizing, Actuating, Controlling, Hotel. 


\section{PENDAHULUAN}

Pertumbuhan dibidang industri pariwisata di Indonesia mengalami kemajuan yang cukup pesat. Hunziger dalam Isdarmanto (2017: 3) menyatakan pariwisata merupakan keseluruhan jaringan dan gejala yang berkaitan dengan orang asing yang tinggal di suatu tempat yang tidak melakukan suatu pekerjaan yang penting yang memberi keuntungan. Perkembangan pariwisata Indonesia yang cukup pesat dapat terlihat dari jumlah kunjungan wisatawan mancanegara ke Indonesia yang meningkat setiap tahunnya. Pada bulan Februari 2019 naik 6,12 persen dibanding jumlah kunjungan pada Februari 2018, yaitu dari 1,20 juta kunjungan menjadi 1,27 juta kunjungan. Grafik perkembangan jumlah kunjungan wisman 2017-2019 (ribu kunjungan) adalah sebagai berikut:

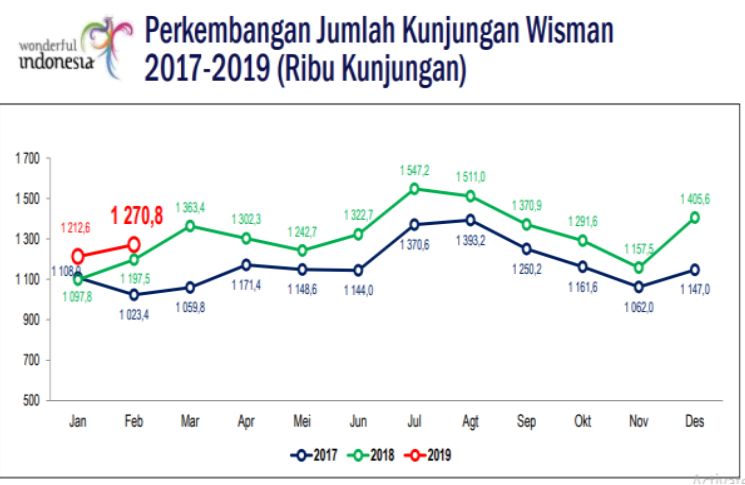

Gambar 1. Grafik Perkembangan Jumlah Kunjungan Wisman (2017-2019)
Event merupakan kegiatan yang diselenggarakan untuk memperingati hal-hal penting baik secara individu maupun kelompok, kegiatan diselenggarakan untuk tujuan tertentu serta melibatkan lingkungan masyarakat. Salah satu tujuan sebuah event diselenggarakan adalah terdapat pada sasaran dan target pengunjung (Noor, 2013). Terdapat empat kriteria manajemen menurut Terry dalam Wijaya dan Rifa'i (2016) yang harus dipenuhi untuk mencapai keberhasilan sebuah event, yaitu planning (perencanaan), organizing (pengorganisasian), actuating (pelaksanaan) dan controlling (pengawasan).

Kyriad Hotel Bumiminang Padang merupakan hotel berbintang empat di Kota Padang yang memiliki arsitektur megah dengan bentuk bangunan modern namun tanpa meninggalkan nilai-nilai tradisional khas Sumatera Barat.Hotel ini memiliki total 164 kamar dan 9 function room yang menjadi penunjang kegiatan operasional hotel

Tabel 1. Kapasitas Function Room Kyriad Hotel Bumiminang Padang

\begin{tabular}{lllllll}
\hline NAME & $\begin{array}{l}\text { CAPACITY } / \text { pax } \\
\text { Round } \\
\text { Uabhape }\end{array}$ & $\begin{array}{l}\text { Class } \\
\text { Room }\end{array}$ & $\begin{array}{l}\text { Board } \\
\text { Room }\end{array}$ & Theatre & Standing \\
\hline Puti Bungsu & 175 & 700 & 600 & 100 & 1200 & 1500 \\
Gumarang & 50 & 80 & 70 & 50 & 100 & 130 \\
Binuang & 25 & 50 & 40 & 25 & 50 & 70 \\
Kinantan & 25 & 50 & 40 & 25 & 50 & 70 \\
Arau & 25 & 50 & 40 & 25 & 50 & 70 \\
Anai & 25 & 50 & 40 & 25 & 50 & 70 \\
Pagaruyuang & 50 & 80 & 70 & 50 & 100 & 130 \\
Sianok & 10 & 10 & 10 & 10 & 20 & 30 \\
Mentawai & 25 & 40 & 30 & 30 & 60 & 80 \\
\hline & & & \multicolumn{3}{l}{ Sumber: Dokumentasi Departemen Sales \& Marketing }
\end{tabular}

Dapat terlihat pada tabel total jumlah event yang terlaksana pada bulan Februari,
Maret dan April di Hotel Kyriad Bumiminang berikut ini: 
Tabel 2. Total Jumlah Event di Kyriad Hotel Bumiminang Padang (2019)

\begin{tabular}{|c|c|c|}
\hline No & Bulan & Jumlah Event \\
\hline 1 & Februari & 95 \\
\hline 2 & Maret & 100 \\
\hline 3 & April & 149 \\
\hline & Total & 344 \\
\hline
\end{tabular}

Berdasarkan sumber pra penelitian pada Bulan April 2019, dari segi perencanaan sering terjadi kesalahan dalam pembuatan BEO. Terdapat kesalahan penulisan jumlah pax pada BEO, seperti contoh jumlah pax yang akan datang berjumlah 110 pax, namun sales admin hanya menulis 100 pax, kesalahan ini nantinya akan berdampak pada delay in service karena harus menyediakan tambahan peralatan dan makanan. Peralatan dan perlengkapan hotel untuk event masih kurang. Beberapa tamu mengaku kurang puas dengan barang-barang yang ada di hotel karena sudah tua. Karyawan juga menjadi kesulitan apabila ada event dengan jumlah peserta yang banyak, karena tidak memeilki cukup peralatan untuk banyak peserta, seperti meja, alas meja dan cutleries. Begitu juga apabila ada tamu yang meminta barang yang tidak dimiliki oleh hotel, seperti pointer dan lainnya. Proses perencanaan merupakan langka awal kegiatan manajemen dalam setiap organisasi, karena pada tahap perencanaan ini akan ditetapkan apa yang akan dilakukan, kapan akan dilakukan dan siapa yang akan melakukan kegiatan tersebut (Wijaya dan Rifa'i, 2016: 28).

Sering terjadinya full capacity di restoran ketika jam makan siang sehingga staff harus set up meja makan dan buffet di ruang meeting atau di lounge disaat last minute yang menyebabkan jadwal makan tamu sedikit mundur, hal ini dikarenakan departemen sales and marketing dan departemen F\&B tidak mengantisipasi jumlah tamu yang akan menggunakan restoran. Kemudian, hotel masih belum memiliki SOP secara tertulis untuk masing-masing departemen, sehingga standar dalam bekerja sehari-hari tidak jelas dan tidak konsisten. Contohnya adalah seperti set up buffet banquet yang berbeda di setiap event. Tidak adanya SOP secara tertulis juga menyebabkan tidak adanya pedoman yang pasti bagi karyawan yang baru bergabung.

Pengorganisasian pada dasarnya merupakan upaya untuk melengkapi rencanarencana yang telah dibuat dengan susunan organisasi pelaksananya. Kerjasama dua orang atau lebih dengan koordinasi yang terpadu untuk mencapai tujuan kelompok adalah organisasi (Mondy \& Premeaux dalam Wijaya dan Rifa'i, 2016: 39). Dari segi organizing (pengorganisasian), hotel terlalu banyak menerima event dalam sebulan sedangkan karyawan dari departemen terkait seperti section banquet kekurangan tenaga, pada saat ini jumlah karyawan banquet adalah 6 orang karyawan sedangkan dalam hari tertentu jumlah event dalam sehari bisa mencapai 7 - 9 event. Hal ini menyebabkan karyawan banquet tidak bisa menangani banyaknya permintaan klien dan karyawan tidak dapat bekerja maksimal dalam menjalankan SOP sehingga menimbulkan komplain tamu. Dapat dilihat pada tabel 3 dibawah ini jumlah event yang confirm di bulan April dan tabel 4 mengenai jumlah karyawan di Departemen F\&B Kyriad Bumiminang, sebagai berikut:

Tabel 3. Jumlah Event pada Bulan Apri/hari (2019)

\begin{tabular}{ll|ll}
\hline Tanggak & Jumlah Event & Tanggal & Jumlah Event \\
\hline 1 & 6 & 16 & 3 \\
2 & 5 & 17 & 0 \\
3 & 5 & 18 & 2 \\
4 & 6 & 19 & 5 \\
5 & 5 & 20 & 5 \\
6 & 3 & 21 & 1 \\
7 & 5 & 22 & 7 \\
8 & 6 & 23 & 7 \\
9 & 5 & 24 & 9 \\
10 & 6 & 25 & 8 \\
11 & 8 & 26 & 4 \\
\hline
\end{tabular}




\begin{tabular}{ll|ll}
\hline 12 & 8 & 27 & 4 \\
13 & 3 & 28 & 7 \\
14 & 3 & 29 & 7 \\
15 & 3 & 30 & 3 \\
\hline
\end{tabular}

Sumber: Data Pra Penelitian, 2019

Dari segi actuating (pelaksanaan), terdapat permasalahan seperti staff banquet hotel tidak standby disaat event berlangsung dan ketika dibutuhkan. Karyawan merasa kurang bersemangat dalam bekerja karena kurangnya pengarahan dan motivasi oleh pihak manajemen hotel sehingga karyawan tidak maksimal dalam memberikan pelayanan kepada tamu. Ketika ada tamu yang meminta pembaruan layout ruangan ataupun penambahan di menit-menit terakhir eventakan dilaksanakan, staff banquet dan staff terkait lainnya kesulitan memenuhi permintaan tamu tepat waktu dan tamu pun tidak puas. Staff tidak membaca BEO dengan seksama dan menyeluruh yang menyebabkan lupa akan detail yang diperlukan di event sehingga tamu komplain karena permintaannya tidak dilaksanakan. Menurut Andriansyah (2017: 22) pengarahan adalah proses mengarahkan karyawan agar dapat bekerja sama dengan memberikan dorongandorongan sehingga menjadi lebih semangat dalam mencapai tujuan organisasi.

Terry dalam Wijaya dan Rifa'i (2016: 46) mengatakan bahwa pengawasan merupakan usaha yang sistematis dalam menentukan apa yang telah dicapai yang mengarah kepada penilaian kinerja dan mengkoreksi atau mengukur kinerja yang didasarkan pada rencana-rencana yang ditetapkan sebelumnya. Dari segi controlling (pengawasan), terdapat permasalahan seperti banyaknya event di hotel membuat staf sales and marketing tidak bisa mengawasi semua event yang berlangsung sehingga tidak dapat memastikan kepuasan tamu ketika event berlangsung. Kemudian daripada itu, pihak hotel belum ada menyediakan semacam feedback form untuk menilai bagaimana kepuasan klien setelah melaksanakan event di Kyriad Bumiminang, sehingga komplain dan masukan dari klien tidak dapat di teruskan kepada departemen yang bersangkutan dan tidak dapat ditindaklanjuti untuk kemajuan penyelenggaraan event selanjutnya.

Manajemen yang baik akan menuntun kepada keberhasilan sebuah event, maka penulis berkeinginan untuk melakukan penelitian mengenai manajemen event di Kyriad Hotel Bumiminang Padang dengan judul "Analisis Manajemen Event di Kyriad Hotel Bumiminang Padang". Pentingnya penelitian ini dilakukan adalah untuk memperbaiki kekurangan-kekurangan dalam manajemen pelaksanaan event sehingga dapat menghasilkan event yang melebihi ekspetasi yang diharapkan klien dan memberikan kesan positif terhadap citra hotel. Penelitian ini diharapkan dapat memperoleh informasi mengenai penyebab permasalahan yang terjadi seputar pelaksanaan event pada saat ini di Kyriad Hotel Bumiminang Padang dan menemukan solusinya yang dipaparkan secara ilmiah.

\section{METODE}

Jenis penelitian ini adalah penelitian deskriptif dengan pedekatan data kualitatif dan kuantitatif dengan metode mixed. Populasi penelitian ini berjumlah 653 orang dengan jumlah sampel 87 orang. Teknik pengambilan sampel yang digunakan pada penelitian ini yaitu probability sampling dengan teknik simple random sampling. Penelitian ini menggunakan data primer dan data sekunder, diperoleh dari observasi, dokumentasi, wawancara dan menyebarkan kuesioner yang terdiri dari 20 pernyataan yang telah diuji validitas dan reliabilitasnya. Selanjutnya data akan diolah menggunakan IBM SPSS versi 25.

\section{HASIL DAN PEMBAHASAN}

\section{A. Pendekatan Kualitatif} 1) Perencanaan

Berdasarkan hasil wawancara, dapat disimpulkan bahwa pihak hotel terutama departemen sales and marketing dan banquet yang berkaitan dengan langsung dengan event belum sepenuhnya melakukan perencanaan dengan baik. Dapat dilihat berdasarkan hasil wawancara, terjadi kesalahan dan keterlambatan dalam merencanakan event, bahkan tim banquet tidak melakukan briefing sama sekali. Padahal briefing di pagi hari ataupun pada saat pergantian shift sangat penting demi kelancaran bekerja sehari-hari, karena pada saat briefing-lah akan dijelaskan lebih rinci mengenai event apa yang akan diselenggarakan, apa saja yang akan dilakukan, apa saja yang harus dipersiapkan dan pengarahan lainnya agar pekerjaan dapat diselesaikan secara efisien 
dan efektif. Tidak matangnya perencanaan tentu akan menimbulkan ketidakpuasan tamu terhadap pelayanan dan produk yang hotel tawarkan.

\section{2) Pengorganisasian}

Struktur organisasi dan pembagian tugas di departemen sales and marketing sudah baik karena struktur organisasi yang sudah jelas dan lengkap. Kemudian pembagian tugasnya juga sudah jelas karena masing-masing sales executive telah dibagi tugasnya sesuai dengan segmentasi yang ada, sehingga mereka bisa fokus pada masing-masing segmen. Namun, di tim banquet struktur organisasinya masih belum lengkap karena kosongnya posisi supervisor dan pembagian tugas masih tidak jelas dan tidak terlaksana dengan baik karena jumlah personil yang kurang dan tidak seimbang dengan jumlah function room yang ada di hotel. Kurangnya jumlah personil di tim banquet mempengaruhi kualitas pelayanan yang diberikan pada tamu, seperti menyebabkan terjadinya delay in service dan kurang fokusnya karyawan pada tugas yang telah diberikan menyebabkan ketidakpuasan tamu dan menimbulkan komplain.

\section{3) Pelaksanaan}

Pelaksanaan event masih belum cukup baik karena beberapa staf masih tidak melakukan tugas dan tanggung jawabnya. Pengecekan ruangan dan lainnya tentu harus dilakukan untuk memastikan semua sesuai dengan permintaan tamu dan tidak menimbulkan komplain, karena jika dari awal acara tamu sudah komplain maka itu akan merusak mood tamu sehingga berkemungkinan untuk timbul komplain lainnya. Pihak manajemen hotel juga harus mempertimbangkan untuk menambah staf yang memiliki kemampuan untuk meningkatkan kualitas pelayanan terhadap tamu.Begitu juga para atasan atau head of departemen harus memastikan bahwa stafnya melaksanakan tugas dan tanggung jawabnya. Kyriad Hotel Bumiminang merupakan hotel tertua di Kota Padang, bangunan dan peralatannya sudah tampak cukup tua, untuk produk mungkin hotel ini tidak mampu bersaing dengan hotel baru lainnya, oleh karena Kyriad Hotel Bumiminang harus unggul di segi pelayanan dan ke-higienisannya.

\section{4) Pengawasan}

Karyawan maupun pihak manajemen selalu berusaha untuk memberikan solusi terhadap kesalahan-kesalahan yang terjadi, namun tindakan koreksi jarang dilakukan padahal dengan dilakukannya tindakan koreksi dapat mencegah terjadi kesalahan yang sama sehingga komplain tamu berkurang. Kemudian, meskipun belum ada standar yang jelas dan tertulis, karyawan selalu berusaha untuk melakukan perkerjaan sesuai dengan standar yang dilakukan secara turun-temurun dari senior sebelumnya, namun karena belum jelasnya standar yang ada membuat butuh waktu bagi karyawan yang baru untuk beradaptasi dan mengingat urutan kerjanya. Diharapkan juga kepada pihak manajemen untuk aktif dan turun kelapangan untuk melihat secara langsung bagaimana operational hotel berjalan salah satunya yaitu penyelenggaraan event di hotel sehingga dapat secara langsung menilai dimana kekurangan selama penyelenggaraan event dan hal-hal apa saja yang bisa ditingkatkan untuk menjadi nilai plus penyelenggaraan event di Kyriad Hotel Bumiminang Padang di mata para konsumen.

\section{B. Pendekatan Kuantitatif}

Data diperoleh dari 20 pernyataan yang disebar kepada 87 orang panitia pelaksana acara yang telah diuji validitas dan reliabilitasnya. Bersumber dari pengisian kuesioner maka dapat diperoleh deskripsi data seperti yang terlihat pada tabel berikut:

Tabel 4. Klasifikasi Skor Variabel Manajemen Event di Kyriad Hotel Bumiminang Padang

\begin{tabular}{llll}
\hline Kategori & Rentang Skor & $\mathbf{f}$ & $\%$ \\
\hline Sangat Baik & $>79,95$ & 2 & 4 \\
Baik & $66,65-<79,95$ & 21 & 41 \\
Cukup Baik & $53,35-<66,65$ & 31 & 36 \\
Kurang Baik & $\mathbf{4 0 , 0 5 - < 5 3 , 3 5}$ & $\mathbf{5 4}$ & $\mathbf{6 2}$ \\
Tidak Baik & $<40,05$ & 0 & 0 \\
$\quad$ Total & & $\mathbf{8 7}$ & $\mathbf{1 0 0}$ \\
\hline
\end{tabular}

Sumber: Hasil Olahan Microsoft Excel, 2019 
Berdasarkan tabel di atas dapat dijelaskan bahwa dari 87 tamu untuk variabel manajemen event di Kyriad Hotel Bumiminang Padang dapat dikelompokkan sebagai berikut: sebanyak $0 \%$ responden menunjukkan kategori sangat baik, $2 \%$ responden menunjukkan kategori baik, 36\% responden menunjukkan kategori cukup baik, 62\% responden menunjukkan kategori kurang baik dan $0 \%$ responden menunjukkan kategori tidak baik.

Berdasarkan hasil penelitian yang peneliti lakukan mengenai analisis manajemen event di Kyriad Hotel Bumiminang Padang diperoleh informasi berdasarkan wawancara yang telah dilakukan bahwa manajemen event di Kyriad Hotel Bumiminang masih memiliki banyak kekurangan seperti tidak adanya standar (SOP) dalam bekerja secara jelas dan tertulis, peralatan dan perlengkapan hotel yang masih belum memadai, masih kurangnya pengarahan oleh atasan kepada bawahan dalam pekerjaan sehari-hari dan masih kurangnya tindakan pengawasan dan koreksi terhadap karyawan-karyawan yang bekerja tidak sesuai dengan standar. Hal ini tidak sesuai dengan teori yang dikemukakan oleh Clayton Reeser dalam buku dasar-dasar manajemen (2016), "Manajemen merupakan pemanfaatan sumber daya psikis dan manusia melalui usaha yang terkoordinasi dan diselesaikan dengan mengerjakan fungsi perencanaan, pengorganisasian, penyusunan staf, pengarahan dan pengawasan".Dari teori tersebut jelas terlihat bahwa manajemen merupakan pemanfaatan sumber daya yang terkoordinasi untuk mencapai tujuan organisasi. Manajemen event di Kyriad Hotel Bumiminang Padang tergolong kurang baik karena memang masih banyak ditemukan kekurangan-kekurangan dimulai dari proses perencanaan hingga terakhir tindakan pengawasan. Sehingga perlu dilakukan perbaikan-perbaikan dalam proses manajemen event supaya berjalan dengan baik dan tujuan tercapai.

Hal diatas juga diperkuat dengan hasil evaluasi berdasarkan pada kuesioner yang telah diisi oleh tamu yang mengadakan event di Kyriad Hotel Bumiminang Padang sebanyak 87 tamu sebagai responden, maka diperoleh hasil sebesar $62 \%$ responden menyatakan kurang baik, 36\% menyatakan cukup baik dan $2 \%$ menyatakan baik. Dari hasil tersebut, diperoleh informasi bahwa secara dominan responden menyatakan bahwa manajemen event di Kyriad Hotel Bumiminang tergolong kurang baik (62\%). Agar tamu merasa puas dengan pelaksanaan event di Kyriad Hotel
Bumiminang Padang, sebaiknya pihak manajemen hotel melakukan perbaikanperbaikan dalam hal manajemen event dimulai dari membuat, menetapkan dan menjalankan standard operational procedure sesuai dengan cakupan kerja masing-masing departemen hingga melakukan koreksi atau penilaian berkaitan dengan hasil kerja.

\section{PENUTUP}

Berdasarkan hasil penelitian yang diperoleh dari observasi, wawancara dan kuesioner, secara keseluruhan manajemen event di Kyriad Hotel Bumiminang Padang masih memiliki kekurangan hal ini diperjelas dengan hasil evaluasi yang menunujukkan sebanyak $62 \%$ menyatakan kurang baik, 36\% menyatakan cukup baik dan $2 \%$ menyatakan sangat baik. Sedangkan berdasarkan masingmasing indikator dapat dilihat sebagai berikut:

a. Indikator perencanaan dalam manajemen event di Kyriad Hotel Bumiminang Padang masih memiliki beberapa kekurangan seperti kurang telitinya sales representative dalam membuat BEO sehingga terjadi kesalahan pemberian informasi ke departemen terkait lainnya. Kemudian masih belum adanya SOP secara tertulis bagi departemen sales marketing dan banquet. Tim banquet tidak melakukan briefing sebelum memulai bekerja sehingga sering terjadi salah komunikasi dan informasi antar anggota, serta masih sering terjadi last minute event yang menyebabkan persiapan untuk event menjadi kurang matang. Hal ini diperkuat dengan hasil evaluasi dari kuesioner yang diisi oleh panitia pelaksana event sebanyak 87 orang, yang menunjukkan sebanyak $51 \%$ responden menyatakan kurang baik.

b. Indikator pengorganisasian manajemen event di Kyriad Hotel Bumiminang Padang pada departemen sales and marketing sudah cukup baik dapat dilihat dari struktur organisasi yang sudah jelas dan jumlah karyawan yang sudah cukup. Pembagian tugas untuk masing-masing karyawan juga sudah jelas menunjukkan bahwa sales manager sebgai atasan sudah mengkoordinasikan staf nya dengan baik. Namun, struktur organisasi di tim banquet masih belum lengkap dan masih kurangnya jumlah karyawan di tim banquet. Hal ini diperkuat dengan hasil evaluasi dari kuesioner yang diisi oleh panitia pelaksana event sebanyak 87 orang, yang 
menunjukkan sebanyak $72 \%$ responden menyatakan kurang baik.

c. Indikator pelaksanaan manajemen event di Kyriad Hotel Bumiminang sudah cukup baik, namun masih ada beberapa hal yang harus ditingkatkan, seperti mengingatkan kembali kepada karyawannya akan tugas dan tanggung jawab masing-masing bagian dan pihak manajemen harus memastikan bahwa tugas dan tanggung jawab karyawannya telah dilaksanakan. Hal ini diperkuat dengan hasil evaluasi dari kuesioner yang diisi oleh panitia pelaksana event sebanyak 87 orang, yang menunjukkan sebanyak $38 \%$ responden menyatakan cukup baik.

d. Indikator pengawasan dalam manajemen event di Kyriad Hotel Bumiminang Padang sudah cukup baik karena event-event yang diselenggarakan dapat berjalan dan tujuan dari event tercapai. Meskipun ditengahtengah penyelenggaraan event masih terdapat beberapa kekurangan yang menimbulkan komplain tamu. Kemudian hotel masih belum menyediakan feedback form sebagai alat ukur kepuasan tamu yang menyelenggarkan event di Kyriad Hotel Bumiminang Padang dan untuk menampung keluhan, kritik dan saran tamu yang nantinya berguna sebagai acuan dalam melakukan evaluasi dan perbaikan untuk masa selamjutnya. Dilihat dari hasil evaluasi berdasarkan kuesioner yang telah diisi responden, sebanyak $44 \%$ responden menyatakan cukup baik.

Adapun saran yang dapat disampaikan penulis dalam penelitian ini adalah

a. Diharapkan kepada pihak manajemen hotel untuk selalu memastikan bahwa kegiatan manajemen event di Kyriad Hotel Bumiminang Padang berjalan dengan semestinya dan memantau apakah tujuan dari manajemen event telah tercapai atau belum.

b. Manajemen event di Kyriad Hotel Bumiminang Padang dilihat dari fungsi perencanaan sudah memiliki standar dalam merencanakan event meskipun belum secara tertulis, akan lebih baik jika pihak manajemen hotel dapat membuat suatu standar dalam bekerja secara tertulis agar dapat dibaca dan dijadikan pedoman oleh karyawan masing-masing departemen.

c. Fungsi pengorganisasian dalam manajemen event di Kyriad Hotel Bumiminang Padang masih memiliki kendala yaitu kurangnya sumber daya manusia di tim banquet, sebaiknya pihak manajemen mempertimbangkan untuk melakukan penambahan karyawan di banquet agar operasional banquet dapat berjalan dengan baik tugas dapat diselesaikan sesuai dengan tujuan.

d. Pelaksanaan event di Kyriad Hotel Bumiminang masih memiliki kekurangan karena ada beberapa tamu yang merasa kurang puas dengan pelayanan selama acara, sebaiknya pihak manajemen hotel selalu memberikan arahan dan motivasi kepada karyawan agar dapat memberikan pelayanan yang terbaik kepada tamu.

e. Agar dapat mengetahui tingkat kepuasan tamu terhadap penyelenggaraan event di Kyriad Hotel Bumiminang Padang, sebaiknya pihak manajemen hotel menyediakan semacam feedback form yang dapat menampung keluhan, kritik dan saran dari tamu. Dari feedback form ini nantinya dapat diambil kesimpulan hal apa saja yang harus dipertahankan dan apa saja yang harus diperbaiki berkaitan dengan manajemen event guna mendatangkan citra positif dalam hal penyelenggaraan event di Kyriad Hotel Bumiminang Padang.

\section{DAFTAR PUSTAKA}

Abdullah, Iqbal Alan. 2009. Manajemen Konferensi dan Event. Yogyakarta: Gajah Mada University Press.

Andriansyah, Rifki. 2017. "Analisis Pelaksanaan Fungsi-Fungsi Manajemen untuk Meningkatkan Aksesibilitas Penyandang Disabilitas pada Pilkada Serentak 2015". Skripsi Bandara Lampung: Fakultas IImu Sosial dan IImu Politik Universitas Lampung.

Arikunto, S. 2013. Prosedur Penelitian: Suatu Pendekatan Praktik. Jakarta: Rineka Cipta.

Handoko, T Hani. 2012. Manajemen Edisi 2. Yogyakarta: BPFE.
Isdarmanto. 2016. Kepariwisataan dan
Dasar-Dasar Destinasi Pariwisata. Pengelolaan Gerbang Media Aksara.

Negoro, Aria Adi dan Rizki Yudhi Dewantara. 2018. "Analisis dan Desain Sistem Informasi Manejemen Event di Perguruan Tinggi". Jurnal Administrasi Bisnis, 61 (1): 20-29. 
Noor, Any. 2013. Manajemen Event. Bandung: Alfabeta.

Pemerintah Indonesia. 1990. UU No. 9 Tahun 1990 tentang Kepariwisataan. Departemen Pariwisata, Jakarta: Sekretariat Negara.

Pudjiastuti, W. 2010.Special Event Alternatif Jitu Membidik Pasar.Jakarta: PT Alex Komputindo.

Pudjiastuti, Wahyuni. 2013. Manajemen Special Event.Jakarta: Kementrian Pendidikan dan Kebudayaan.

Rosyida, Satwika. 2016. " Analisis Manajemen Event Gumelem Ethnic Carnival Tahun 2016 dalam Melestarikan Kebudayaan di Gumelem, Banjarnegara”. Skripsi.Yogyakarta: Program Studi IImu Komunikasi Universitas Islam Indonesia.

Saputro, Johan. 2014. "Perencanaan Event Manajemen Festival Kesenian Yogyakarta sebagai Media Komunikasi Identitas Yogyakata". Skripsi. Yogyakarta: Program Studi IImu Komunikasi Universitas Islam Negeri Sunan Kalijaga Yogyakarta.

Sayoga, dkk. 2016. "Analisis Karakteristik Event Ohle Goes To Kampus Sebagai Strategi Komunikasi Pemasaran PT Pikiran Rakyat". E-Proceeding of Management.Bandung.

Septemuryantoro, Syaiful Ade dan Cindy Citya Dima. 2018. "Pembelajaran Wisata MICE (Meeting Incentive Conference Exhibition) untuk Menciptakan SDM MICE di Kalangan Mahasiswa Perhotelan Universitas Dian Nuswantoro". Prosiding SENDI_U. Semarang: 407-412.

Siregar, Damara Saputra. 2014. "Pelaksanaan Manajemen Mice (Meeting Incentive Conference Exhibition) Di Hotel Pangeran Pekanbaru". Jom FISIP, 1 (2): 1-12.

Sondang, Siagan. 2012. Fungsi-fungsi manajemen. Jakarta: Bumi Aksara.

Sugiyono. 2014. Metode Penelitian Pendidikan Pendekatan Kuantitatif, Kualitatif dan R\&D. Bandung: Alfabeta.
Sulistyowati, Nina dan Eka Harisma. 2016. Manajemen Event. Jakarta: PDD AKN Kabupaten Demak.

Wijaya, Candra dan Muhammad Rifa'i (Ed). 2016. Dasar-Dasar Manajemen. Medan: Perdana Publishing. 